\title{
HUBUNGAN ANTARA KREATIVITAS BERWIRAUSAHA DENGAN MINAT BERWIRAUSAHA PERBENGKELAN OTOMOTIF SISWA SMK
}

\author{
Maun Sugiarto ${ }^{1}$, Inu H. Kusuma ${ }^{2}$, Tatang Permana ${ }^{3}$ \\ Departemen Pendidikan Teknik Mesin \\ Universitas Pendidikan Indonesia \\ Jl. Dr. Setiabudhi No. 207 Bandung 40154 \\ maun.sugiarto@gmail.com
}

\begin{abstract}
ABSTRAK
Penelitian ini bertujuan untuk mengetahui besar hubungan antara kreativitas berwirausaha dengan minat berwirausaha perbengkelan otomotif pada mahasiswa paket keahlian otomotif. Metode yang digunakan yaitu metode deskriptif dengan teknik pengumpulan data berupa angket. Berdasarkan hasil pengolahan data menunjukkan bahwa tingkat kreativitas berwirausaha dikalangan mahasiswa paket keahlian otomotif tergolong pada kategori sedang, sedangkan minat berwirausaha mahasiswa paket keahlian otomotif berada dalam kategori tinggi. Hasil penelitian menunjukkan bahwa korelasi antara kreativitas berwirausaha dan minat berwirausaha sebesar 0,335. Angka tersebut menunjukkan bahwa besarnya hubungan antara kreativitas berwirausaha dengan minat berwirausaha perbengkelan otomotif pada mahasiswa paket keahlian otomotif berada pada kategori rendah.
\end{abstract}

Kata kunci: kreativitas, kewirausahaan, minat, otomotif, bengkel.

\section{PENDAHULUAN}

Kewirausahaan merupakan salah satu kunci untuk meningkatkan daya saing bangsa adalah dengan meningkatkan jumlah kewirausahaan, baik sisi kualitas maupun kuantitasnya. Jumlah wirausahawan menjadi sangat penting untuk sebuah bangsa karena kehadiran wirausahawan yang unggul dalam dalam kualitas membuat perekonomian negara semakin sejahtera dan kuat. Melalui pendidikan formal salah satunya dengan pendidikan kewirausahaan melalui mata kuliah kewirausahaan diharapkan agar lulusan perguruan tinggi disiapkan menjadi sosok yang mandiri dan tidak selalu terfokus menjadi pencari kerja atau menjadi karyawan melainkan mampu menciptakan lapangan pekerjaan. Berdasarkan hasil survei Badan Pusat Statistik (2014) merilis jumlah pengangguran pada agustus 2013 sebayak 7,39 juta orang.

Secara umum menunjukkan bahwa makin tinggi jenjang pendidikan, makin besar jumlah pengangguran, terkecuali pada jenjang SMA/SMK. Fenomena ini disebabkan karena beberapa faktor, sedikitnya ketersediaan lapangan pekerjaan sesuai dengan lulusan, terlalu mengandalkan ijazah dan terlalu berorientasi pada pencarian kerja. Dengan demikian peluang

\footnotetext{
${ }^{1}$ Mahasiswa Departemen Pendidikan Teknik Mesin FPTK UPI

${ }^{2}$ Dosen Departemen Pendidikan Teknik Mesin FPTK UPI

${ }^{3}$ Dosen Departemen Pendidikan Teknik Mesin FPTK UPI
} 
kerja menjadi semakin sedikit untuk para pencari kerja, dengan berwirausaha harapanya dapat menekan angka penganguran terutama pada lulusan perguruan tinggi, yang selalu berorientasi mencari kerja atau menjadi tenaga kerja di perusahaan atau lembaga. Dengan hanya mengandalkan ijazah dan mencari kerja menunjukan sikap kurangnya minat berwirausaha terutama pada lulusan perguruan tinggi.

Jumlah lulusan perguruan tinggi yang tidak seimbang dalam penerimaan lapangan kerja membuat tidak sedikit lulusan pergurauan tinggi yang menjadi pengangguran, serta masih berfikir untuk menjadi pekerja dibanding membuat lapangan kerja. Salah satu faktor yang mempengaruhi minat berwirausaha adalah faktor internal yang terdiri dari kemampuan afektif dan kemampuan kognitif. Kemampuan afektif mencakup sikap, nilai, aspirasi, perasaan dan emosi yang semuanya bergantung pada lingkungan yang ada. Sedangkan kemampuan kognitif adalah pengetahuan mengenai kewirausahaan yang tercemin melalui proses dan hasil pembelajaran kewirausahaan. Kewirausahaan adalah suatu proses penerapan kreativitas dan inovasi dalam memecahkan persoalan dan menemukan peluang untuk memperbaiki kehidupan yang di tumbuhkan melalui minat (Suryana, 2006).

Tujuan penelitian ini untuk mengetahui gambaran kreativitas berwirausaha pada mahasiswa paket keahlian otomotif; untuk memperoleh gambaran mengenai minat berwirausaha perbengkelan otomotif pada mahasiswa paket keahlian otomotif; dan untuk mengetahui besarnya hubungan kreativitas berwirausaha terhadap minat berwirausaha perbengkelan otomotif pada mahasiswa paket keahlian otomotif.

Kreativitas merupakan kemampuan umum untuk menciptakan sesuatu yang baru, sebagai kemampuan untuk gagasan yang baru yang dapat diterapkan sebagai pemecahan masalah atau sebagai kemampuan untuk melihat hubungan-hubungan baru atas unsur-unsur yang sudah ada (Munandar, 2009). Perbuatan yang mengarahkan kepada suatu tujuan dan merupakan suatu dorongan hasil interaksi dengan dunia luar, berupa keingintahuan dan rasa senang terhadap apa yang diminatinya. Dalam diri manusia terdapat dorongan-dorongan dan keinginan yang mendorong manusia untuk berinteraksi dengan dunia luar, dan apa yang sudah menjadi minat seseorang mendorongnya untuk berbuat lebih giat dan lebih baik (Purwanto, 2006).

Kreativitas merupakan kemampuan untuk menggabungkan atau menghubungkan hal baru atas unsur-unsur yang sudah ada, sehingga kreativitas berwirausaha memiliki hubungan 
terhadap minat berwirausaha. Minat berwirausaha perbengkelan otomotif dalam penelitian ini yaitu dorongan dan keinginan untuk melakukan kegiatan perintisan usaha perbengkelan otomotif didasari atas keingintahuan, rasa senang, berorientasi masa depan, serta memiliki kesungguhan untuk terlibat dalam dalam pengembangan minat terhadap kegiatan perintisan usaha perbengkelan otomotif.

\section{METODE PENELITIAN}

Metode penelitian yang digunakan dalam penelitian ini adalah deskriptif korelasi. Melalui metode penelitian deskriptif dapat diperoleh deskripsi mengenai hubungan antara kerativitas berwirausaha dan minat berwirausaha mahasiswa. Sedangkan penelitian korelasi bertujuan untuk menguji apakah terdapat hubungan kerativitas berwirausaha terhadap minat berwirausaha. Teknik penentuan sampel yang dilakukan dalam penelitian ini menggunakan teknik random proportional sampling, yaitu metode pengambilan sampel yang tiap unsur pembentuk populasi diberi kesempatan yang sama terpilih menjadi sampel, dengan jumlah populasi sebanyak 185 mahasiswa dan ukuran sampel sebanyak 65 orang.

Pengumpulan data pada penelitian ini menggunakan angket, dimana angket merupakan teknik pengumpulan data yang dilakukan dengan cara memberi seperangkat pertanyaan atau pernyataan tertulis kepada responden untuk dijawabnya, jawaban responden adalah data yang digunakan dalam penelitian. Jumlah keseluruhan pernyataan angket berjumlah 103 dengan angket pernyataan kreativitas berwirausaha sebanyak 75 butir dan angket minat berwirausaha sebanyak 28 butir. Angkat yang digunakan pada penelitian ini menggunakan angket yang

sudah digunakan dan diuji, angket kreativitas berwirausaha menggunakan angket yang dikembangkan oleh princenton creative research sedangkan angket minat berwirausaha menggunakan penelitian kontribusi mata pelajaran kewirausahaan terhadap minat berwirausaha pada bidang otomotif. Instrumen penelitian ini sudah diuji sehingga instrument ini tidak diperlukan pengujian kembali pada penelitian ini.

\section{HASIL PENELITIAN}

Hasil penelitiann mengenai kreativitas berwirausaha pada mahasiswa paket keahlian otomotif telah diperoleh. 
Tabel 1. Nilai kreativitas berwirausaha

\begin{tabular}{cccc}
\hline Rentang skor & Kategori & Frekuensi & Persentase $(\%)$ \\
\hline $\mathrm{X}<223.75$ & Sangat Rendah & 7 & 10.8 \\
$223.75 \leq \mathrm{X} 236.5$ & Rendah & 13 & 20 \\
$236.25 \leq \mathrm{X}<248.75$ & Sedang & 18 & 27.7 \\
$248.75 \leq \mathrm{X}<261.25$ & Tinggi & 21 & 32.3 \\
$\mathrm{X} \geq 261.25$ & Sangat Tinggi & 6 & 9.2 \\
Jumlah & & 65 & $100 \%$ \\
\hline
\end{tabular}

Kreativitas berwirausaha (Tabel 1) terdapat 7 mahasiswa yang termasuk kepada kategori sangat rendah dengan persentasi 10.8\%. Sebanyak 13 mahasiswa yang termasuk kepada kategori rendah dengan persentase 20\%. Sebanyak 18 mahasiswa yang termasuk kepada kategori sedang dengan persentase 27.7\%. Sebanyak 21 mahasiswa yang termasuk kepada kategori tinggi dengan persentase 32.3\% dan mahasiswa yang termasuk kepada kategori sangat tinggi dengan persentase 9.2\%. Hal tersebut menunjukan bahwa mayoritas mahasiswa paket keahlian otomotif berada pada kategori tinggi namun jika diambil dari skor rata-rata yaitu sebesar 244 berada pada kategori sedang.

Hasil perhitungan analisis data untuk hasil akhir minat berwirausaha diperoleh jumlah skor 6560 skor rata-rata 101, skor tertinggi 135, skor terendah 32. Berikut gambaran mengenai minat berwirusaha perbengkelan otomotif pada mahasiswa angkatan 2008-2012 paket keahlian otomotif.

Tabel 2. Nilai minat berwirausaha perbengkelan otomotif

\begin{tabular}{cccc}
\hline Rentang skor & Kategori & Frekuensi & Persentase(\%) \\
\hline $\mathrm{X}<57.5$ & Sangat Rendah & 1 & 1.5 \\
$57.5 \leq \mathrm{X}<74.92$ & Rendah & 2 & 3 \\
$74.92 \leq \mathrm{X}<92.08$ & Sedang & 12 & 18.46 \\
$92.08 \leq \mathrm{X}<111.24$ & Tinggi & 39 & 60 \\
$\mathrm{X} \geq 111.24$ & Sangat Tinggi & 11 & 9.2 \\
Jumlah & & 65 & $100 \%$ \\
\hline
\end{tabular}

Minat berwirausaha perbengkelan otomotif (Tabel 2) terdapat 1 mahasiswa yang memiliki kriteria sangat rendah dengan persentasi 1.5\%. Sebanyak 2 mahasiswa memiliki kriteria rendah dengan persentase 3\%, 12 mahasiswa memiliki kriteria sedang dengan 
persentase $18.46 \%$, 39 mahasiswa berkriteria tinggi dengan persentase $60 \%$ dan 11 mahasiswa berkriteria sangat tinggi dengan persentase 9.2\%. Hal tersebut menunjukkan bahwa mayoritas mahasiswa paket keahlian otomotif memiliki minat yang tinggi untuk menjadi seorang wirausaha perbengkelan otomotif.

Nilai koefisien korelasi antara variabel kreativitas berwirausaha (X) dengan minat berwirausaha (Y) sebesar 0.335. Apabila di interpretasi ke dalam tabel interpretasi koefisien korelasi. Hasil korelasi tersebut berada dalam kategori sedang dengan arah hubungan yang linear positif. Hasil uji t bahwa variabel kreativitas berwirausaha (X) memiliki $t_{\text {hitung }}>t_{\text {tabel }}$ $(2.825>1.670)$. Hasil tersebut dapat diartikan yakni menolak Ho dan menerima Ha. Ini berarti bahwa kreativitas berwirausaha mempunyai hubungan terhadap minat berwirausaha perbengkelan otomotif.

\section{PEMBAHASAN}

Hasil yang diperoleh dari penelitian menunjukkan bahwa kreativitas berwirausaha di kalangan mahasiswa paket keahlian otomotif , dari 65 mahasiswa terdapat 7 mahasiswa yang termasuk kepada kategori sangat rendah dengan persentasi 10.8\%, 13 mahasiswa yang termasuk kepada kategori rendah dengan persentase 20\%, 18 mahasiswa yang termasuk kepada kategori sedang dengan persentase 27.7\%, 21 mahasiswa yang termasuk kepada kategori tinggi dengan persentase $32.3 \%$ dan mahasiswa yang termasuk kepada kategori sangat tinggi dengan persentase 9.2\%. Hal tersebut menunjukan bahwa mayoritas mahasiswa paket keahlian otomotif berada pada kategori tinggi, namun jika diambil dari skor rata-rata yaitu sebesar 244 berada pada kategori sedang. Data tersebut menunjukan sebagai gambaran umum atau tingkat kreativitas berwirausaha dikalangan mahasiswa paket keahlian otomotif angkatan 2008-2012 UPI itu sedang.

Hasil analisis data yang dilakukan untuk melihat tingkat minat berwirausaha perbengkelan otomotif di kalangan mahasiswa paket keahlian otomotif UPI angkatan 20082012 menunjukan bahwa dari 65 mahasiswa didapat hasil sebanyak 1 mahasiswa (1.5\%) termasuk kedalam kategori yang memiliki minat berwirausaha sangat rendah, 2 mahasiswa (3\%) termasuk dalam kategori yang memiliki minat berwirausaha yang rendah, 12 mahasiswa (18.46\%) termasuk dalam kategori siswa yang memiliki minat berwirausaha sedang, 39 mahasiswa (60\%) termasuk dalam kategori mahasiswa yang memiliki minat berwirausaha 
yang tinggi, dan 11 mahasiswa $(9.2 \%)$ termasuk dalam kategori sangat tinggi. Data tersebut merupakan temuan yang menunjukkan sebagai gambaran atau tingkat minat berwirausaha perbengkelan otomotif di kalangan mahasiswa paket keahlian otomotif UPI angkatan 20082012 itu berada pada kategori tinggi (Arif, 2012).

Hasil penelitian menjelaskan bahwa kreativitas berwirausaha memiliki hubungan yang positif dan signifikan terhadap minat berwirausaha perbengkelan otomotif. hubungan antara variabel $\mathrm{X}$ terhadap variabel $\mathrm{Y}$ dapat dilihat pada persamaan regresi: $\hat{\mathrm{Y}}=7.07+0.38 \mathrm{X}$. Arti persamaan regresi ini yaitu jika terjadi perubahan atau peningkatan satu kesatuan unit variabel $\mathrm{X}$ akan menyebabkan variabel $\mathrm{Y}$ berubah atau meningkat sebesar 0.38 unit satuan. Sehingga meningkatnya nilai kreativitas berwirausaha akan diikuti meningkatnya minat berwirausaha perbengkelan otomotif (Sardiman, 2008).

Hasil uji keberartian regresi didapat nilai signifikan 0,006 <0,05. Hasil perhitungan ini menjelaskan terdapat hubungan yang linier antara variabel X dengan Variabel Y. Jika nilai kreativitas berwirausaha besar, maka akan semakin tinggi minat berwirausaha perbengkelan otomotif.

Berdasarkan hasil analisis korelasi, dihasilkan koefisien korelasi 0,335. Hasil perhitungan ini menjelaskan kreativitas berwirausaha sebagai variabel $\mathrm{X}$, mempunyai korelasi sedang terhadap minat berwirausaha perbengkelan otomotif sebagai variabel $\mathrm{Y}$. Hasil perhitungan koefisien korelasi tersebut diyakinkan dengan uji signifikansi koefisien korelasi dengan menghitung nilai $\mathrm{t}$, dimana hitung $>\mathrm{t}$ tabel $(2.825>1.670)$, sehingga dapat diartikan menolak Ho dan menerima $\mathrm{Ha}$, atau kreativitas berwirausaha memiliki hubungan positif terhadap minat berwirausaha perbengkelan otomotif.

\section{KESIMPULAN}

Kesimpulan penelitian ini, yaitu kreativitas berwirausaha di kalangan mahasiswa angkatan 2008-2012 paket keahlian Otomotif tergolong pada kategori sedang. Minat berwirausaha di kalangan di kalangan mahasiswa angkatan 2008-2012 paket keahlian Otomotif tergolong pada kategori tinggi. Terdapat hubungan yang positif antara kreativitas berwirausaha dengan minat berwirausaha perbengkelan otomotif di kalangan mahasiswa angkatan 2008-2012 paket keahlian Otomotif. 


\section{DAFTAR PUSTAKA}

Arif, B, (2012). Deskripsi Teori Hakikat Minat. (Online), Tersedia: http:eprints.uny.oc.id/7633/3/Bab\% 202\%20 -\%2008601244086.pdf. (14-8-2014).

Munandar, U. (2009). Kreativitas dan Keberbakatan: Stragetik Mewujudkan Potensi Kreatif dan Bakat. Jakarta: PT Gramedia Pustaka Utama.

Purwanto, N. (2006). Psikologi Pendidikan. Bandung: PT Remaja Rosdakarya.

Sardiman. A. M. (2008). Interaksi dan Motivasi Belajar Mengajar. Jakarta: PT. Raja Grafindo Persada.

Suryana. (2006). Kewirausahaan Pedoman Praktis: Kiat dan Proses Menuju Sukses. Jakarta: Salemba Empat. 